Original Research Paper

\title{
Pelatihan Budidaya Sayuran Hidroponik Menggunakan Sistem Wicks Sebagai Usaha Pemberdayaan Masyarakat di Desa Cenggu
}

\author{
Annisa Mujriati ${ }^{1}$, Khairatun Nafisah ${ }^{2}$, Khusnul Hayatunnisa ${ }^{3}$, Lalu Japa ${ }^{4 *}$

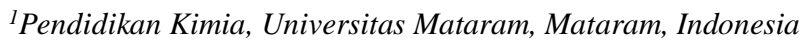 \\ ${ }^{2}$ Pendidikan Matematika,, Universitas Mataram, Mataram, Indonesia \\ ${ }^{3}$ Pendidikan Bahasa dan Sastra Indonesia,, Universitas Mataram, Mataram, Indonesia \\ ${ }^{4}$ Pendidikan Biologi, Universitas Mataram, Mataram, Indonesia
}

DOI: https://doi.org/10.29303/jpmpi.v4i2.717

Sitasi: Mujriati, A., Nafisah, K., Hayatunnisa, K., \& Japa, L. (2021). Pelatihan Budidaya Sayuran Hidroponik Menggunakan Sistem Wicks Sebagai Usaha Pemberdayaan Masyarakat di Desa Cenggu. Jurnal Pengabdian Magister Pendidikan IPA, 4(2)

\section{Article history}

Received: 23 Maret 2021

Revised: 20 Mei 2021

Accepted: 21 Juni 2021

*Corresponding Author: Lalu

Japa, Pendidikan Biologi,

Universitas Mataram, Mataram,

Indonesia;

Email: 1japa@unram.ac.id

\begin{abstract}
Berdasarkan analisis situasi diketahui bahwa sebagian besar masyarakat Desa Cenggu bermata pencarian di sektor pertanian dan produk yang dihasilkan berupa kacang kedelai, padi dan bawang merah tetapi untuk jenis tanaman sayuran produksinya sangat rendah dan bahkan tidak dibudidayakan oleh penduduk setempat. Padahal, potensi pengembangan pertanian pada skala rumah tangga atau perkarangan cukup besar. Tujuan program ini adalah: (1) memberdayakan masyarakat Desa Cenggu dengan memberikan pelatihan budidaya tanaman sayuran dengan hidroponik sistem wick. (2) meningkatkan pengetahuan masyarakat tentang teknik hidroponik. Konsep hidroponik merupakan budidaya menanam dengan memanfaatkan air/larutan bernutrisi tanpa menggunakan medium tanah dengan menekankan pada pemenuhan kebutuhan nutrisi. Metode yang digunakan dalam program ini adalah sosialisasi program, pelatihan dan praktik pembuatan hidroponik dan pendampingan serta evaluasi kegiatan. Hasil dari program yang dijalankan yaitu terlaksanannya sosialisasi kepada masyarakat yang ditandai dengan terbentuknya model hidroponik yang siap digunakan oleh masyarakat dan setiap warga memiliki hidroponik di rumah masing-masing di area perkarangan rumah.
\end{abstract}

Keywords: Budidaya; Sayuran; Hidroponik; Sistem Wick; Pelatihan; Pemberdayaan

\section{Pendahuluan}

Cenggu merupakan salah satu Desa di Kecematan Belo, Kabupaten Bima, Provinsi Nusa Tenggara Barat. Desa Cenggu memiliki luas wilayah $720.70 \mathrm{Ha}$ dengan jumlah penduduk 3.220 jiwa. Sebagian besar masyarakat Desa Cenggu bermata pencarian di sektor pertanian dan produk yang dihasilkan berupa kacang kedelai, padi, dan bawang merah dari hasil kegiatan di ladang sedangkan untuk jenis tanaman sayuran produksinya sangat rendah bahkan tidak dibudidayakan oleh masyarakat Desa Cenggu.. Hal ini disebabkan kurangnya minat serta pengetahuan masyarakat tentang budidaya tanaman jenis sayuran. Padahal untuk menanam jenis sayuran bisa lakukan di pekarangan rumah masing-masing, sehingga pengolahan lahan pekarangn rumah menjadi lebih produktif.

Kebutuhanakan hasil pertanian terus meningkat seiring jumlah penduduk yang semakin bertambah. Salah satu kebutuhan hasil pertanian yang dibutuhkan penduduk setempat adalah hasil 
tanaman sayuran sebagai bahan pangan kebutuhan sehari-hari. Sementara hasil pertanian jenis tanaman sayuran sangat rendah di Desa Cenggu. Kondisi yang demikian membutuhkan solusi untuk mengatasinya. Salah satunya dengan memanfaatkan lahan perkarangan rumah untuk dijadikan sebagai lahan budidaya sayuran. Apabila dimanfaatkan secara optimal maka permasalahan tersebut, kemungkinan besar dapat diatasi atau paling tidak dapat dikurangi.

Salah satu teknik bercocok tanaman sayuran yang dapat diterapkan oleh masyarakat adalah teknik hidroponik sistem wick. Hidroponik adalah suatu metode bercocok tanam tanpa menggunakan media tanah, melainkan dengan menggunakan larutan mineral bernutrisi atau bahan lainnya yang mengandung unsur hara seperti sabut kelapa, serat mineral, pasir, pecahan batu bata, serbuk kayu, dan lain-lain sebagai pengganti media tanah. Teknologi budidaya pertanian dengan sistem hidroponik diharapkan menjadi salah satu alternatif bagi masyarakat yang mempunyai lahan terbatas atau pekarangan, sehingga dapat dijadikan sebagai sesuatu yang berguna (Mulasari, 2019). Sistem Tanam secara hidroponik bisa dilakukan secara kecil-kecilan di rumah sebagai suatu hobi ataupun secara besar-besaran dengan tujuan komersial. Budididaya tanaman secara hidroponik tidak memerlukan lahan yang luas, bisa juga dilakukan di pekarangan rumah. Perawatan hidroponik sangat mudah, karena tumbuhan, tanaman atau sayursayuran dapat tumbuh dengan mudah tanpa menggunakan tanah, hanya dengan talang air, botol-botol kemasan yang sudah tidak terpakai dan juga bisa memanfaatkan barang-barang yang sudah tidak diperlukan seperti ember, baskom dan sebagainya (Satya, et al., 2017).

Beberapa jenis hidroponik yakni wick, (DWC), (hood \& Drain), (NFT) dan Aeroponik. Dalam kegiatan ini digunakan jenis Hidroponik sistem wick. Hidroponik sistem wick salah satu metode dari hidroponik yang menggunakan sumbu atau penyambung antara nutrisi dengan media tanam. Sistem ini yang paling simpel dan sederhana. Sumbu yang digunakan adalah sumbu yang memiliki daya kapilaritas tinggi serta tidak cepat melapuk Cara ini sama dengan mekanisme kompor minyak, yaitu sumbu berfungsi untuk menyerap air. Sumbu terbaik adalah kain flanel maka cocok digunakan untuk sistem wick. Kelebihan dan kekurangan sistem hidroponik wick adalah tanaman mendapat suplai air dan nutrisi secara terus-menerus, biaya alat yang murah, mempermudah perawatan karena tidak perlu melakukan penyiraman, dan tidak tergantung aliran listrik (Narulita, 2019). Prinsip hidroponik sistem sumbu sangat mudah diaplikasikan, karena memiliki tingkat kesulitan yang sangat rendah. Selain itu semua bahan untuk membuat instalasi hidroponik bisa diperoleh dengan barang-barang bekas (Kamala, et al., 2017). Alat yang digunakan dalam kegiatan ini mengunakan barang bekas di sekitar rumah atau limbah rumah tangga, seperti botol air mineral, kain fanel, gelas plastik dan lainnya sementara barang-barang tersebut memiliki manfaat untuk dijadikan media tanam hidroponik sehingga diperoleh suatu ide program untuk memberikan pelatihan/pemberdayaan kepada masyarakat Desa Cenggu.

Pemberdayaan adalah keadaan yang terjadi atau hal-hal yang dilakukan di lingkungan masyarakat dengan upaya membangun pembangunan yang bertumpu pada masyarakat itu sendiri. Tujuan dilakukan pemberdayaan ini adalah membuat masyarakat menjadi berdaya dalam berinovasi dalam bisang tertentu, termasuk dalam sektor pertanian. Berdaya yang dimaksud disini ialah upaya-upaya atau unsur-unsur yang meningkatkan masyarakat untuk bertahan dan mengembangkan diri untuk mencapai kemajuan. Maju yang dimaksud adalah untuk memajukan perekonomian seiring dengan majunnya pengetahuan dan tingkat penguasaan teknologi sumber daya manusia (Solikhah, et al., 2018). Adapun pemberdayaan yang akan dilakukan adalah dengan memberikan sosialisasi dan pelatihan mengenai bercocok tanam sistem hidroponik. Pemilihan pemberdayaan masyarakat Desa Cenggu dalam memberikan pelatihan hidroponik dengan alasan sebagai: (1) Masyarakat Desa Cenggu memiliki lahan yang cukup untuk diterapkan sebagai lahan tanaman hidroponik dan sebagian besar masyarakat Desa Cenggu khusus ibu rumah tangga tidak memiliki pekerjaan sampingan sehingga bercocok tanam dapat meningkatkan perekonomian keluarga. (2) Bercocok tanam dengan hidroponik tidak membutuhkan lahan yang luas. (3). Teknologi hidoroponik menggunakan sistem yang sederhana yakni sistem sumbu (wick system). (4). Dapat menstabilkan hasil perekonomian masyarakat Desa Cenggu khususnya di bahan pangan sayuran serta dapat menghemat 
pengeluaran. (5). Barang -barang bekas yang tidak bernilai dapat dimanfaatkan sebagai media tanam hidroponik yang tersedia melimpah di masyarakat Desa Cenggu.

Berdasarkan latar belakang tersebut maka diperlukan suatu upaya untuk memperkenalkan usulan program berupa pelatihan budidaya tanaman sayuran hidroponik dengan sistem wick sebagai usaha memberdayakan masyarakat di Desa Cenggu.

\section{Metode}

Untuk mencapai target luaran yang telah direncanakan, program ini melalui beberapa tahapan sebagai berikut:

\section{Sosialisasi Program}

Sosialisasi Program Hidroponik ini melibatkan masyarakat khusunya ibu-ibu rumah tangga dengan menggunakan Metode ceramah interaktif secara langsung. Adapun beberapa hal yang disampaikan pada saat sosialisasi yaitu: (a) pentingnya pemberdayaan ibu rumah tangga, (b) Pengenalan hidroponik sistem sumbu, (c) kelebihan hidroponik sistem sumbu.

\section{Pelatihan dan Praktik Pembuatan Hidroponik}

Setelah seluruh warga masyarakat khususnya ibu-ibu rumah tangga memahami materi tentang hidroponik, selanjutnya adalah pelatihan membuat tanaman hidroponik mulai dari proses pembuatan tempat tanam, pembibitan sampai dengan proses pembuatan pupuk organik cair untuk tanaman hidroponik. Praktek yang dilaksanakan adalah pembuatan hidroponik yang menggunakan sistem wicks. Adapun alat dan bahan yang dapat digunakan untuk membuat hidroponik sistem ini adalah sebagai berikut: (a) botol bekas (b) kain flanel (c) gelas plastik tempat tanam (d) rockwol (e) nutrisi/pupuk organik cair (f) benih sayuran (g) cat warna. Budidaya sayuran secara hidroponik dilakukan dengan tahap langkah berikut: (1) semaikan bibit pada media rockwol, (2) masukan bibit yang sudah berumur seminggu ke lubang tanam, pada media tanam rockwool yang telah ditaruh di dalam gelas yang dilengkapi kain flanel sebagai sumbu untuk mengalirkan air dan nutrisi, (3) isi bak penampung dengan air dan nutrisi sesuai takaran, (4) tambahkan air dan nutrisi setiap minggu, dan tunggu sampai sayuran budidaya siap dipanen.

\section{Pendampingan}

Untuk memastikan, bahwa program dapat berjalan sesuai dengan yang diharapkan, maka tahapan berikutnya yang dijalankan adalah pendampingan. Proses pendampingan dilaksanakan secara fisik datang langsung ke rumah warga. cara tersebut dirasa lebih efektif dan efisien dikarenakan masyarakat dapat terlibat dan melihat langsung proses pembuatan alatnya, pembibitan dan pembuatan pupuk organik cair. Tujuan dari program ini adalah untuk mendampingi serta memantau pelaksanaan program pemberdayaan masyarakat melalui pelatihan Hidroponik ini.

\section{Evaluasi Kegiatan}

Untuk mengetahui keberhasilan dari kegiatan ini maka evaluasi dilakukan dengan cara sebagai berikut: (1). Kegiatan pemaparan materi dievaluasi berdasarkan partisipasi peserta atau masyarakat setempat serta keaktifan peserta. Apabila tingkat partisipasi minimal mencapai $60 \%$ dari seluruh peserta yang direncanakan maka kegiatan ini dianggap berhasil. Keaktifan peserta dan keefektifan pemaparan dinilai dari interaksi peserta selama pelaksanaan pemaparan materi. (2). Evaluasi utama atas program kegiatan ini, adalah apabila target dari program ini tercapai yaitu setiap warga memiliki hidroponik di rumah masingmasing (di area perkarangan rumah). Adapun pelaksanaan program kegiatan KKN dianggap berhasil apabila minimal terdapat 15 warga yang berhasil membuat tanaman hidroponik khususnya tanaman berupa sayur-sayuran, selain itu juga dilihat dari tingkat keberhasilan tanaman hidroponik sampai hasil panen.

\section{Hasil dan Pembahasan}

Kegiatan program KKN ini terbagi menjadi 3 program besar yaitu kegiatan sosialisasi dan pelatihan guna penyampaian materi terkait hidroponik dan program praktik pembuatan hidroponik system wick. Adapun tahapan yang dilakukan dalam kegiatan ini adalah:

\section{Sosialisasi Budidaya Sayuran Hidroponik Sistem Sumbu}

Teknik hidroponik sistem sumbu merupakan salah satu sistem hidroponik yang paling sederhana dan mudah dilakukan oleh kalangan pemula. Sistem ini menggunakan tangki yang berisi larutan 
nutrisi. Nutrisi mengalir ke dalam media pertumbuhan dari dalam wadah menggunakan sejenis sumbu yang biasanya adalah kain flanel. Prinsip yang diterapkan pada sistem ini adalah kapilaritas (Puspasari et al., 2018).

Sosialisasi program dilakukan dilakukan terhadap masyarakat setempat sebagai mitra pelaksanaan program ini (Gambar 1). Adapun materi yang disampaikan yaitu: (a) pentingnya pemberdayaan ibu rumah tangaa, (b) pengertian hidroponik sistem sumbu, (c) kelebihan hidroponik sistem sumbu. Pada kegiatan sosialisasi tersebut Kepala Desa dan masyarakat memberikan apresiasi yang tinggi terhadap program yang diusung dan berharap keberlanjutan program bisa tetap terjamin.

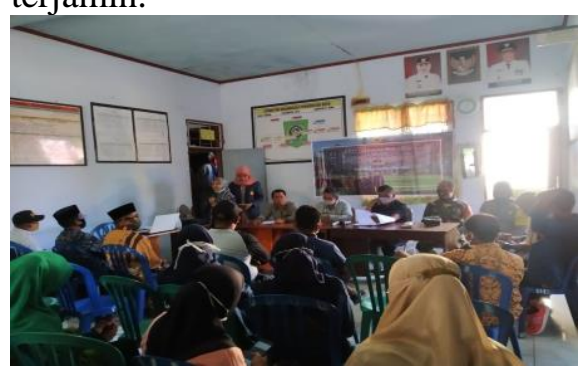

Gambar 1. Sosialisasi budidaya sayuran hidroponik sistem sumbu

\section{Pelatihan Budidaya Sayuran Hidroponik Sistem Sumbu}

Kegiatan pelatihan dimaksudkan untuk memberikan pemahaman kepada masyarakat target sasaran/ibu-ibu rumah tangga tentang cara bercocok tanaman hidroponik sistem sumbu. Pelatihan budidaya sayuran bagi ibu-ibu RT 10/RW 04 dengan sistem sumbu ini menggunakan tanaman kangkung dan sawi. Adapun kegiatan pelatihan dilakukan selama 1 kali sebagai berikut:

\section{a. Pelatihan Semai Bibit}

Pelatihan penyemaian bibit merupakan realisasi dari kegiatan sosialisasi. Pelatihan di ikuti oleh para ibu rumah tangga (Gambar 2). Pelatihan ini dimulai dari persiapan alat dan bahan dan proses penyemaian bibit.

Tahap pertama dari pelatihan ini adalah penyiapan alat dan bahan yang digunakan untuk penyemaian bibit.Alat dan bahan yang digunakan adalah rockwool, bibit, air, nampan/tray semai, dan tusuk gigi.

Tahap selanjutnya adalah proses penyemaian bibit. Media tanam yang digunakan menggunakan rockwool. Rockwool dipotong dengan ukuran menyesuaikan lebar gelas plastik air mineral bekas, kemudian dibuat lubang tanam, 4 lubang untuk bibit kangkung dan 1 lubang untuk bibit sawi menggunakan tusuk gigi. Selanjutnya rockwool diberi air hingga basah. Benih dimasukan ke lubang tanam.



Gambar 2. Suasana pelatihan semai bibit sayuran

\section{b. Pelatihan Pembuatan Larutan Nutrisi}

Pelatihan pembuatan pupuk organik cair merupakan realisasi dari kegiatan sosialisasi (Gambar 3). Pelatihan diikuti oleh para ibu rumah tangga. Pelatihan ini dimulai dari persiapan alat dan bahan, proses pembuatan dan pengemasan.

Tahap pertama pelatihan ini adalah penyiapan alat dan bahan yang digunakan untuk pembuatan pupuk organik cair. Alat yang digunakan adalah botol bekas, baskom, pisau, ulekan/blender, pengaduk, dan corong. Sedangkan bahan baku yang dibutuhkan adalah pisang kapok, cangkang telur, air cucian beras, EM4 dan gula pasir.

Tahap selanjutnya adalah proses pembuatan pupuk organik cair dengan tahapan berikut: (1) pisang dipotong dengan ukuran 3-4 cm, lalu dimasukkan kedalam botol, (2) cangkang telur dihancurkan sampai halus, dimasukkan 8 sendok gula ke dalam air cucian beras kemudian diaduk sampai gula tersebut larut, (3) dicampurkan cangkang telur yang sudah halus kedalam campuran gula dan air cucian beras, diaduk hingga tercampur rata kemudian ditungkan dalam botol yang sudah berisi pisang kapok, (4) dimasukkan 3 $\mathrm{ml}$ cairan EM4 ke dalam botol yang sudah terisi pisang kapok, gula, cangkang telur, dan air cucian 
beras, lalu dikocok hingga merata, (5) disimpan campuran pupuk organik tersebut selama 7 hari di tempat yang gelap.

Setelah didiamkan selama 7 hari, langkah terakhir adalah pengemasan pupuk organik cair (POC) ke dalam botol plastik. Campuran POC yang sudah matang/siap pakai akan beraroma alami fermentasi/tape. Larutan tersebut kemudian disaring menggunakan penyaring untuk mendapatkan larutan yang bebas dari padatan bahan baku. Larutan POC yang sudah dikemas dalam botol siap diaplikasikan sebagai alternatif pengganti $A B$ Mix pada system penanaman hidroponik.



Gambar 3. Suasana pelatihan pembuatan pupuk organik cair

\section{c. Pelatihan Penanaman dan Pemeliharaan}

Pelatihan penanaman dan pemeliharan tanaman hidroponik sistem sumbu diikuti oleh para ibu rumah tangga (Gambar 4). Pelatihan penanaman dimulai dari persiapan alat dan bahan dan proses pembuatan dan pelatihan pemeliharan dimulai dari pemberian nutrisi dan pengendalian hama.

Cara yang dapat diterapkan dalam penanaman hidroponik sangat sederhana, yaitu sebagai berikut : (1) bibit semai pada media rockwool, (2) bibit yang sudah tumbuh (kira-kira butuh waktu seminggu), (3) masukkan bibit sayuran ke lubang tanam, media tanam memakai rockwool yang telah ditaruh di dalam gelas dan diberi kain flanel sebagai sumbu untuk mengalirkan air dan nutrisi, (4) isi bak penampung dengan nutrisi sesuai takaran, (5) tambahkan air dan nutrisi setiap minggu, (6) tunggu hingga tanaman siap dipanen (Ruswaji dan Chodariyanti, 2019).

\section{(1). Pelatihan Penanaman}

Pelatihan ini dimulai dari persiapan alat dan bahan, proses pembuatan tempat penanaman dan proses pemindahan hasil semai ke dalam gelas plastik.
Tahap pertama adalah persiapan alat dan bahan. Alat yang digunakan adalah gelas plastik air mineral bekas, botol air mineral bekas, gunting, cutter, kain flanel, TDS meter, ember, penggaris, pensil, kompor, cat. Bahan yang digunakan adalah benih, pupuk organik cair dan air.

Tahap kedua adalah proses pembuatan tempat tanam. Botol bekas air mineral di lubangi pada bagian samping sesuai ukuran gelas plastik air mineral dan di cat sesuai dengan warna yang diinginkan, jarak antar lubang di sesuaikan. Gelas plastik air mineral di lubangi pada bagian bawah dan samping, dan tambahkan kain flanel di bagian bawah gelas air mineral. Masukan air nutrisi ke dalam botol plastik yang telah dilubangi.

Tahap selanjutnya adalah pemindahan hasil semai ke dalam gelas plastik. Pemindahan hasil semai dilakukan dengan cara memotong rockwool yang berisi bibit yang sudah berusia 7 hari, selanjutnya masing-masing kubus rockwool diletakkan dalam gelas air mineral. Susun gelas air mineral yang sudah berisi bibit siap ditanam pada lubang yang tersedia di botol plastik bekas

\section{(2). Pelatihan Pemeliharaan}

Pelatihan ini dimulai dari pemberian nutrisi dan pengendalian hama.

\section{(a). Pemberian Nutrisi}

Nutrisi diberikan setiap 1 minggu sekali larutan nutrisi dicek EC dan pHnya. Jika nilai EC turun maka tambahkan nutrisi dalam larutan, sebaliknya jika nilai EC tinggi, tambahkan air ke dalam larutan. Derajat keasaman air $(\mathrm{pH})$ yang digunakan adalah 6,5-7. Nilai $\mathrm{pH}$ diukur dengan menggunakan $\mathrm{pH}$ meter. Jika nilai $\mathrm{pH}$ turun tambahkan $\mathrm{KOH}$ pada larutan, dan jika nilai $\mathrm{pH}$ naik tambahkan $\mathrm{HCl}$ hingga $\mathrm{pH}$ menjadi stabil 6,57,0. Jika air di bagian bawah botol habis, segera ditambahkan dengan mengukur $\mathrm{pH}$ dan nutrisinya, agar tanaman tidak menjadi kering (Eddy, et al., 2019).

\section{(b). Pengendalian Hama dan Penyakit}

Pengendalian hama dan penyakit dilakukan secara manual, dengan cara mengambil hama yang menyerang tanaman. Apabila tanaman kangkung dan sawi terserang penyakit, sebaiknya segera dibuang, untuk mencegah terjadinya penularan ketanaman lain (Eddy, et al., 2019). 


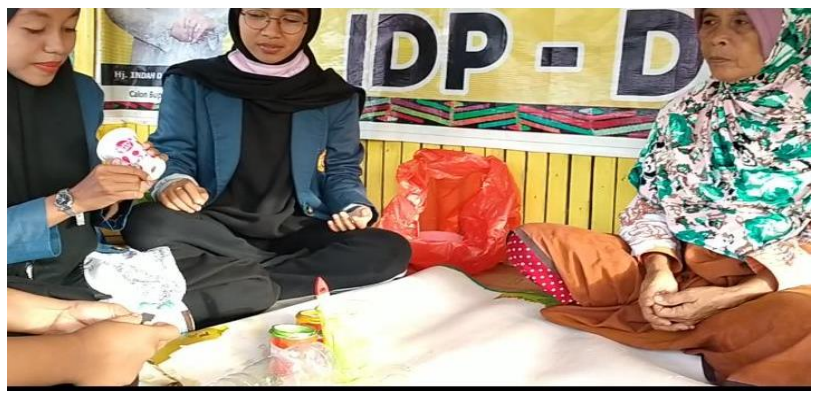

Gambar 4. Suasana pelatihan teknik penanaman hidroponik

\section{Praktik Pembuatan Hidroponik Sistem Sumbu}

Setelah dilakukan sosialisasi dan pelatihan maka selanjutknya adalah melakukan kegiatan praktek langsung, persiapan benih sampai menjadi bibit telah dilakukan. Setelah bibit berusia 1 minggu bibit siap ditanam di media hidroponik, dengan tetap harus dikontrol dan dievaluasi pertumbuhannya serta melakukan perawatan dengan mengganti larutan nutrisi tanaman.

Selanjutnya sampai waktu panen tiba harus tetap melakukan monitoring terhadap pertumbuhan tanaman, rutin mengontrol air dan member nutrisi pada tanaman yang dilakukan setiap 7 hari sekali sehigga secara otomatis bisa mengamati langsung bagaimana proses pertumbuhan tanaman (Gambar 5). Pada saat ini sekaligus juga bisa dikontrol hama atau penyakit yang menyerang, namun pada umunya penanaman hidroponik mampu meminimalisir serangan hama dan penyakit jadi penggunaan pestisida kimia dapat dihindari, sehingga otomatis tanaman dari hasil hidroponik tentunya akan lebih sehat (Ariati dan Raka, 2019).

Panen dilakukan ketika tanaman berusia 30 hari setelah melihat kondisi sayuran tumbuh dengan subur dan yang sudah siap panen (Gambar 6 dan 7).

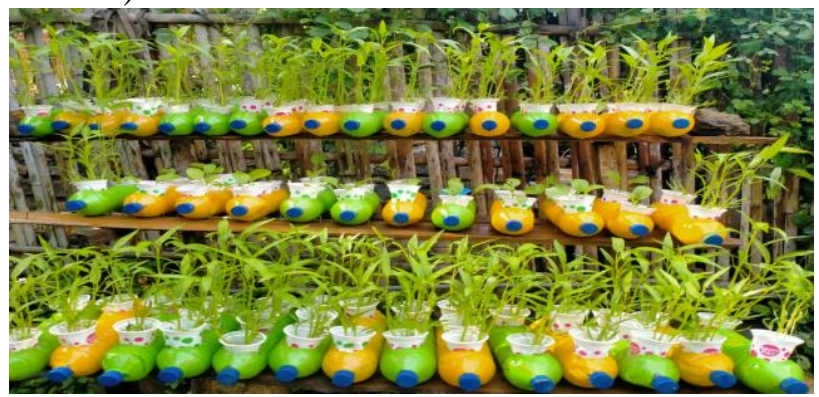



Gambar 5. Tanaman sayuran hidroponik sistem sumbu

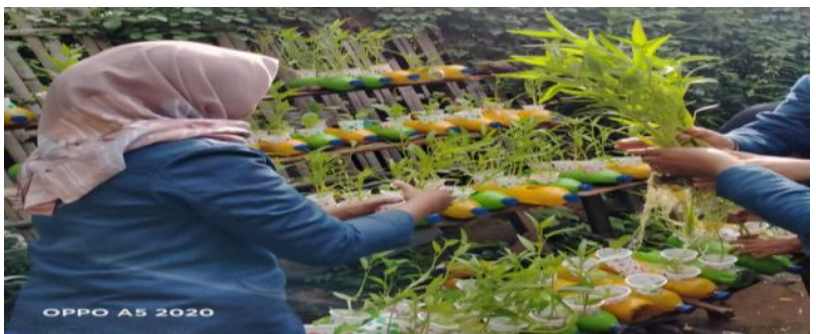

Gambar 6. Proses panen sayuran hidroponik

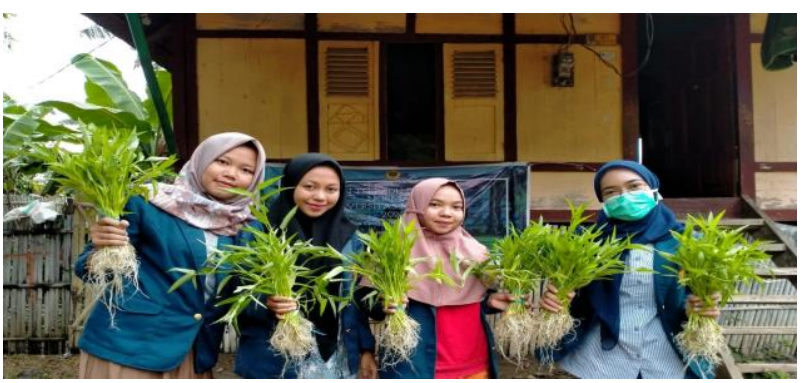

Gambar 7. Hasil tanaman sayuran hidroponik

\section{Kesimpulan}

Berdasarkan hasil program yang dijalankan dapat disimpulkan, bahwa sosialisasi budidaya tanaman sayuran hidroponik sistem sumbu sebagai usaha pemberdayaan masyarakat Desa Cenggu dalam meningkatkan pengetahuan, minat dan keterampilan masyarakat untuk memanfaatkan perkarangan rumah sebagai lahan penaman sayuran hidroponik sistem sumbu. Kegiatan ini juga dapat mendorong kemandirian ekonomi masyarakat dengan mengurangi biaya belanja sayuran rumah tangga sehari-hari. Masyarakat memberikan respon yang sangat positif terhadap kegiatan yang dilakukan dan menilai kegiatan ini sangat bermanfaat.

\section{Daftar Pustaka}

Ariati, P.E.P. dan I.D.N. Raka. 2019. Sosialisasi Hidroponik Sebagai Basis Peningkatan 
Perekonomian Masyarakat Merupakan Pendongrak Nilai Tambah Pendapatan Keluarga. Agrimeta: Jurnal Pertanian Berbasis Keseimbangan Ekosistem. 9(17):53-69.

Eddy, S., D. Mutiara, T. Kartika, C. Masitoh, dan Wahyu. 2019. Pengenalan Teknologi Hidroponik dengan Sistem Wick (sumbu) bagi Siswa SMAN Negeri 2 Kabupaten Rejang Lebong Bengkulu. PengabdianMu: Jurnal Ilmiah Pengabdian kepada masyarakat. 4(2):74-79.

Kamala S., P. Dewanti, dan R. Soedradjad. 2017. Teknologi Hidroponik Sisten Sumbu pada Produksi Selada Lollo Rossa (Lactuca sativa L.) dengan Penambahan $\mathrm{CaCl}_{2}$ Sebagai Nutrisi Hidroponik. Jurnal Agroteknologi. 11(1):96-103.

Mulasari, S.A. 2019. Penerapan Teknologi Tepat Guna (Penanaman Hidroponik Menggunkan Media Tanam) Bagi Masyarakat Sosrowijawa Yogyakarta. Jurnal Pemberdayaan: Publikasi Hasil Pengabdian kepada Masyarakat. 2(3) :425-430.

Narulita, N. 2019. Pengaruh Sistem dan Konsentrasi Nutri Terhadap Pertumbuhan dan Produksi Tanaman Pakcoy (Brassica rapa L) Secara Hidroponik. Agricultural Research Journal. 15(3):99-108.

Puspasari, I., Y. Triwidyastuti, dan H. Harianto. 2018. Otomasi Sistem Hidroponik Wick Terintegrasi pada Pembibitan Tomat Ceri. Jurnal Nasional Teknik Elektro dan Teknologi Informasi (JNTETI). 7(1):97-104.

Ruswaji, R. dan L. Chodariyanti. 2019. Pemberdayaan Masyarakat Desa Kepada Kelompok Ibu-ibu PKK dan Karang Taruna Melalui Program Pelatihan "Hidroponik". Abdimas Berdaya: Jurnal Pengabdian Masyarakat. 2(1):1-9.

Satya, M.T., A. Tejaningrum, dan Hanifah. (2017). Manajemen Usaha Budidaya Hidroponik. Jurnal Dharma Bhakti Ekuitas. 1(2):53-57.

Solikhah, B., T.S. Suryarini, dan A. Wahyudin. 2018. Pemberdayaan Ibu Rumah Tangga Melalui Pelatihan "Hidroponik". Jurnal Abdimas. 22(2):121-127. 